\title{
Review
}

\section{Traditional and Modern Biomedical Prospecting: Part II-the Benefits}

\section{Approaches for a Sustainable Exploitation of Biodiversity (Secondary Metabolites and Biomaterials from Sponges)}

\author{
Werner E.G. Müller ${ }^{1}$, Heinz C. Schröder ${ }^{1}$, Matthias Wiens ${ }^{1}$, \\ Sanja Perović-Ottstadt ${ }^{1}$, Renato Batel $^{2}$ and Isabel M. Müller ${ }^{1}$
}

${ }^{1}$ Institut für Physiologische Chemie, Abteilung Angewandte Molekularbiologie, Universität, Duesbergweg 6, D-55099 Mainz; Germany and ${ }^{2}$ Center for Marine Research, Ruder Boskovic Institute, HR-52210 Rovinj, Croatia

\begin{abstract}
The progress in molecular and cell biology has enabled a rational exploitation of the natural resources of the secondary metabolites and biomaterials from sponges (phylum Porifera). It could be established that these natural substances are superior for biomedical application to those obtained by the traditional combinatorial chemical approach. It is now established that the basic structural and functional elements are highly conserved from sponges to the crown taxa within the Protostomia (Drosophila melanogaster and Caenorhabditis elegans) and Deuterostomia (human); therefore, it is obvious that the molecular etiology of diseases within the metazoan animals have a common basis. Hence, the major challenge for scientists studying natural product chemistry is to elucidate the target(s) of a given secondary metabolite, which is per se highly active and selective. After this step, the potential clinical application can be approached. The potential value of some selected secondary metabolites, all obtained from sponges and their associated microorganisms, is highlighted. Examples of compounds that are already in medical use (inhibition of tumor/virus growth [arabinofuranosyl cytosine and arabinofuranosyl adenine]), or are being considered as lead structures (acting as cytostatic and anti-inflammatory secondary metabolites [avarol/avarone], causing induction of apoptosis [sorbicillactone]) or as prototypes for the interference with metabolic pathways common in organisms ranging from sponges to humans (modulation of pathways activated by fungal components [aeroplysinin], inhibition of angiogenesis [2-methylthio-1,4napthoquinone], immune modulating activity [FK506]) are discussed in this study. In addition, bioactive proteins from sponges are listed (antibacterial activity [pore-forming protein and tachylectin]). Finally, it is outlined that the skeletal elements-the spicules-serve as blueprints for new biomaterials, especially those based on biosilica, which might be applied in biomedicine. These compounds and biomaterials have been isolated/studied by members of the German Center of Excellence BIOTECmarin. The goal for the future is to successfully introduce some of these compounds in the treatment of human diseases in order to raise the public awareness on the richness and diversity of natural products, which should be sustainably exploited for human benefit.
\end{abstract}

Keywords: bioactive compounds - biosilica - evochemistry - natural products - sponges

For reprints and all correspondence: Prof Dr WEG Müller, Institut für Physiologische Chemie, Abteilung Angewandte Molekularbiologie, Universität, Duesbergweg 6, 55099 Mainz; Germany. Tel: +6131-3925910; Fax:+6131-3925243. E-mail: WMUELLER@mail.UNI-MAINZ.de
The first part of this review, Traditional and Modern Biomedical Prospecting: Part I-the History. Sustainable Exploitation of Biodiversity (Sponges and Invertebrates) in the Adriatic Sea in Rovinj (Croatia), by Werner EG Müller, Renato Batel, Heinz C Schröder and Isabel M Müller appeared recently in Evidence-based Complementary and Alternative Medicine 2004;1:71-82.

The online version of this article has been published under an open access model. Users are entitled to use, reproduce, disseminate, or display the open access version of this article provided that: the original authorship is properly and fully attributed; the Journal and Oxford University Press are attributed as the original place of publication with the correct citation details given; if an article is subsequently reproduced or disseminated not in its entirety but only in part or as a derivative work this must be clearly indicated. 


\section{Rationale}

Until six years ago, it was assumed that the approaches of combinatorial chemistry to identify compounds for biomedical application, as drugs or biomaterials, might be the only promising route to identify lead structures for therapeutic use. However, presently, bioprospecting of secondary metabolites from marine sessile filter feeders appears superior to the chemical approach. The change toward this paradigm is surely based on the progress achieved in the identification and structure analysis of natural compounds using methods such as the analytical hyphenation triad (HPLC-MS/MS-NMR-CD) introduced by Bringmann (1). Another major progress attributed to the renaissance of the natural products, especially those from lower invertebrates, was achieved after the causal, analytic screening, based on the achievements in molecular-chemical ecology, proved to be successful $(2,3)$. Particularly, the comprehensive understanding of the molecular biology of the sponges, and to some extent, also that of other sessile filter feeders, provided the impetus for this rational screening approach. It could be demonstrated that (i) the gene repertoire of the sponges (phylum Porifera) is highly diverse $(4,5)$, and (ii) the basic structural, metabolic and disease-related pathways in these animals are closely related to those found in other metazoans including humans (4). One example is the finding that the sponge secondary metabolite, 2-methylthio-1,4-napthoquinone, causes an inhibition of canal formation in sponges as well as of vessel formation in the chick chorioallantoic membrane assay (6).

In view of these (unexpected) findings, an accelerated progress in the identification of new lead compounds useful for biomedical application can be expected. In recent and comprehensive reviews $(7,8)$ a wide activity spectrum of secondary metabolites has been highlighted. Moreover, it has become increasingly obvious that the economical value of natural products (secondary metabolites) for potential biomedical application is by far higher than that of compounds obtained by chemical synthesis. It has been estimated that among a given number of 5000 to 10000 chemically synthesized compounds, only 10 reach clinical phase I, because it is only at this step that the evidence of the concept can be assessed (9) (Fig. 1). In contrast, the evidence of the concept of secondary metabolites, i.e., whether a given compound actually comprises biological activity, has been provided for free by nature (10). Only those secondary metabolites that are biologically active could survive during the long evolutionary history; they were even fortified with respect to selectivity and biological activity in the subsequent rounds of evochemical selection.

Focusing on sponges, a conceptual progress occurred with the study of Thakur (11), who suggested that these animals and their symbiotic microorganisms (bacteria and fungi) produce an array of bioactive compounds against foreign attackers. A recent concept is the notion that symbiosis is driven by environmental biotic constraints (Fig. 2). FIRST (DIRECT PROTECTION): The host (sponge) synthesizes bioactive compounds that provide protection against attacking microorganisms or eukaryotes, e.g., acetylenic compounds (12). The symbiotic bacteria or fungi produce secondary metabolites that act as antibiotics, e.g., cribrostatin (13), or as cytostatic agents, e.g., sorbicillactone A (14). Functionally, these compounds act (most probably) only as defense molecules. SECOND (DIRECT PROTECTION): Another functional class of secondary metabolites of sponges and their associated microorganisms play a dual role; they are involved in defense as well as in the activation of pathways crucial for self-defense (metabolic activator). The first proven example is that of okadaic acid. We could demonstrate that okadaic acid is produced in the sponge Suberites domuncula by bacteria; it acts firstly as a defense molecule against foreign metazoan attackers and simultaneously by a positive modulation of those pathways, which augment the immune response of the host (15). THIRD (IMMUNE PROTECTION): The sponge produces proteinaceous bioactive molecules that arrest the growth of bacteria, e.g., perforin (11) and tachylectin (16), or that destroy eukaryotic cells, e.g., agglutinins (17). FOURTH (INDIRECT PROTECTION): If required, the sponge host harbors selected bacterial strains on its surface that produce bioactive compounds acting specifically against fouling bacteria (11), e.g., tribromophenol (18).

\section{Combinatorial chemistry}

[5 - 10,000 chemicals synthesized]
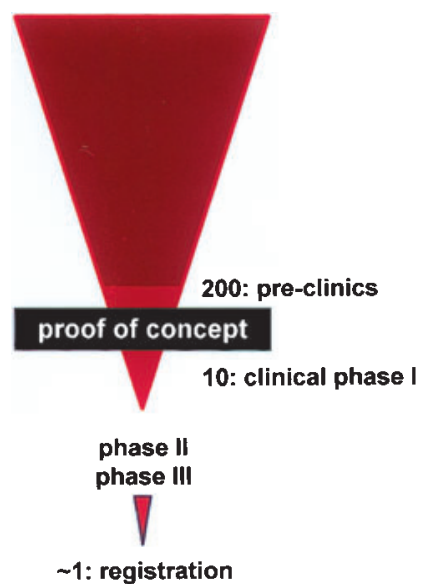

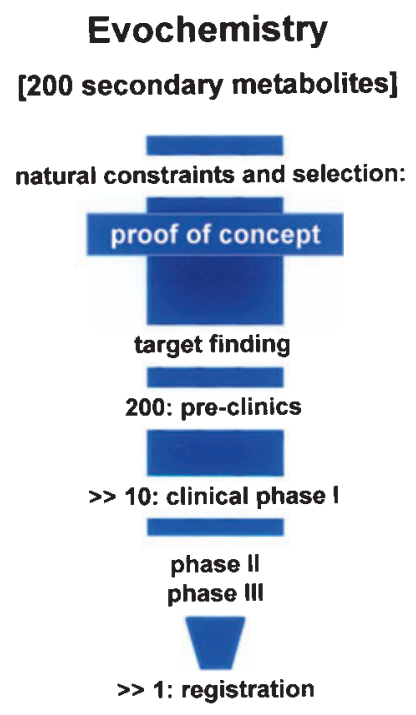

Figure 1. High value of (natural) secondary metabolites in comparison with compounds obtained by combinatorial chemistry. Left: The number of chemicals synthesized solely in a combinatorial chemical manner, which have potential biomedical value, decreases drastically during the preclinical and clinical screening/testing phases. If at all, very few compounds reach the stage of registration (9). Right: Natural secondary metabolites are per se biologically active. If the biological target of a given compound could be identified, (ideally) all of them can reach the clinical phases. 


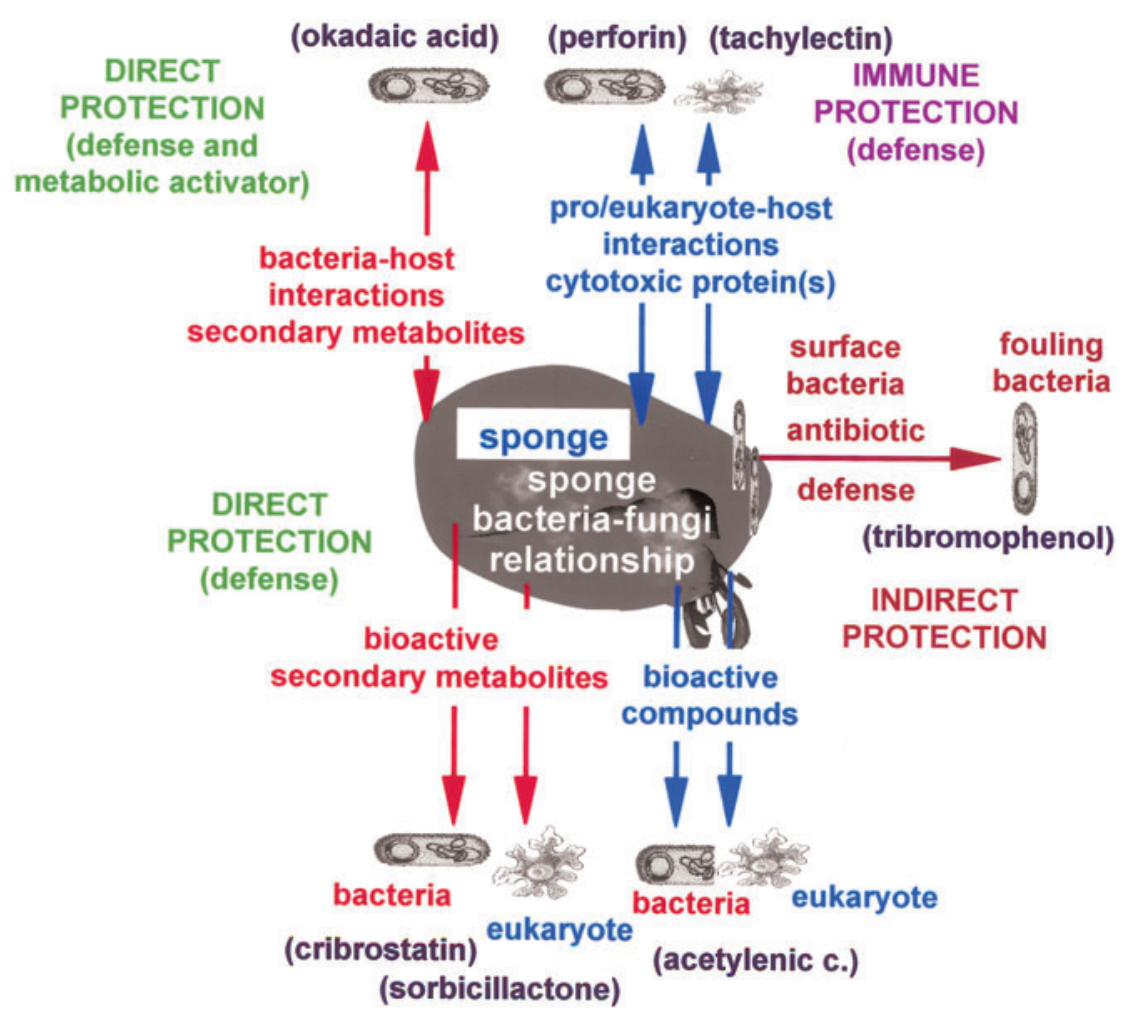

Figure 2. Strategies of sponges, together with their symbiotic microorganisms, bacteria and fungi, for protection against attackers. Sponges are provided with two forms of direct protections; (i) single protection and (ii) dual protection. In single protection, bioactive molecules are produced which are directed only toward the invading pro- and eukaryotic organisms. In the dual form of protection, the secondary metabolites are directed against the non-self organisms and also positively modulate the host metabolism. (iii) The sponges produce defense proteins that neutralize/kill foreign prokaryotic pathogenic microorganisms and eukaryotic predators (immune protection). (iv) The sponges facultatively comprise surface bacteria that produce antifouling secondary metabolites (indirect protection). The red arrows indicate bacterial origin, and the blue ones indicate that the compounds are produced by sponges. Examples of secondary metabolites and proteins involved in these strategies of protection are provided.

It must be stressed that recently, virus-related genes have also been identified in $S$. domuncula, indicating that sponges may also be infected by viruses. This conclusion is not surprising considering the fact that the virus load of the water filtrated by the sponges is considerably high; up to $10^{8}$ virus particles per $\mathrm{ml}$ have been determined in aquatic environments $(19,20)$.

\section{Selected Bioactive Compounds from Marine Sponges and Associated Microorganisms: Low Molecular Weight Compounds}

Providing a comprehensive overview of the secondary metabolites that have been isolated until now from sponges and their associated microorganisms is outside the scope of this review; during 1998 to 1999 , more than 2000 original studies have been published (8), and bioactive compounds are reviewed regularly $(7,21,22)$. In this paper, we focus on those compounds which were discovered by members of the German Center of Excellence 'BIOTECmarin'.

This consortium has selected the Adriatic Sea, in the vicinity of Rovinj (Croatia), as its field station. This area is characterized by a high abundance of species, especially with respect to sponges-approximately 200 species have been described. Furthermore, in accordance with the tradition of this Institute
(Center of Marine Research) since 1891, the laboratory is well equipped, and the infrastructure is highly competent (10). It is very interesting that this northern Adriatic region changed into a marine environment only after the post-pleistocenic rise of the sea level. This transgression occurred only 10000 years ago. Five kilometers north of Rovinj, the unique underwater biotope-the 'Limski Canal' (a fjord-like bay) — protrudes into the interior of the peninsula. Presently, this canal is $11 \mathrm{~km}$ long. Old maps such as the one from Ortelius (1580), depict the canal as being connected with a $20 \mathrm{~km}$ long river (Lemo fl. in Fig. 3 [left]). This 'river Draga' does not carry water any more; it is a dry valley. This geological change, the drying up of the river feeding the Limski Canal, caused dramatic effects on the human population, e.g., on villages such as Dvigrad that were abandoned (in the year 1631). In addition, it most certainly affected the marine biotic populations in the Limski Canal. This tectonic, and consequently also ecological, change might be one of the reasons why this biotope and the organisms in the Limski Canal are considerably different from those in the open sea (23). Perhaps, this difference is also an evolutionary cause for the development of endemic species described in the Limski Canal, e.g., the sponges Tethya limski (24), Geodia rovinjensis (25) and Thoosa istriaca (26).

These unique local conditions resulted in the protection of the Limski Canal as a distinguished marine protected area devoted to evo-devo studies. 

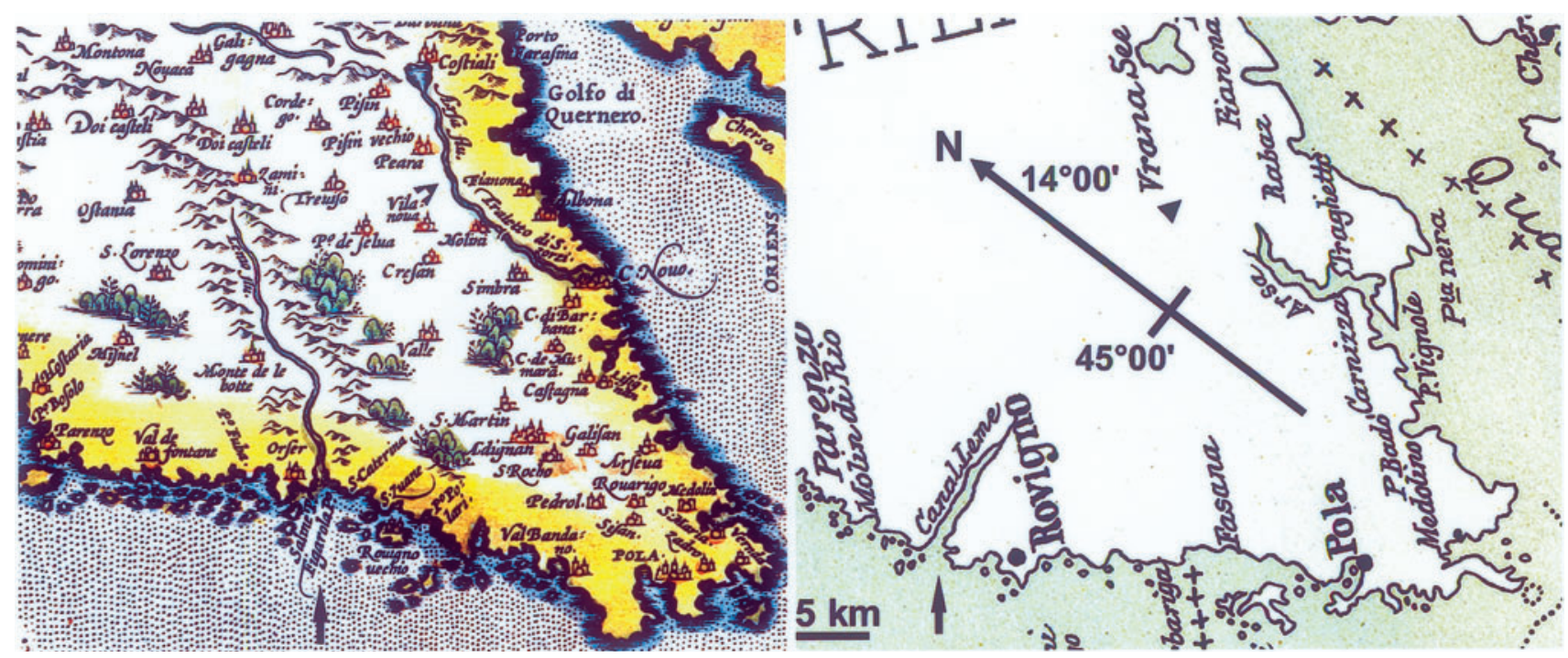

Figure 3. Research area around Rovinj (Croatia). Left: A map of Ortelius (year 1580 [Histriae tabula a Petro Coppo]) depicting the Limski Canal (arrow) with the connected river Lemo flumen. It has its source in the $20 \mathrm{~km}$ distant mountains. Right: A map from 1900 (67), showing the $11 \mathrm{~km}$ long Limski Canal. Similarly, another river (Arsa flumen) (arrow head), which had been connected with the lake Vrana in the year 1580, disappeared later. In the Limski Canal, endemic sponge species, e.g., Tethya limski, Geodia rovinjensis and Thoosa istriaca have been described. The scale bar is provided close to the location of Rovinj.

\section{Inhibition of Tumor/Virus Growth: Arabinofuranosyl Cytosine-Arabinofuranosyl Adenine}

To date, only two compounds, $1-\beta$-D-arabinofuranosyl cytosine and 1- $\beta$-D-arabinofuranosyl adenine, that had been modified from a secondary metabolite isolated from a sponge, Cryptotethya crypta, are in clinical use (27). Species related to this taxon are Tethya lyncurium and Tethya limski, which are found in the Rovinj area (Fig. 4Ac and Ad). T. lyncurium is also the sponge species about which the oldest descriptions $(28,29)$ are available (Fig. 4Aa and Ab). 1- $\beta$-D-arabinofuranosides of thymine and uracil were isolated and used as 'blueprints' for the development of drugs to treat cancer (1- $\beta$-D-arabinofuranosyl cytosine $[$ ara-C]) or herpes simplex virus infection (1- $\beta-D-$ arabinofuranosyl adenine [ara-A]) (Fig. 4B).

Arabinofuranosyl cytosine: The usefulness of ara-C as a potential anticancer drug can be traced back to Cohen (30). As summarized in this review, ara-C potently inhibits the growth of leukemia cells in vitro and in vivo, and is still very frequently used in human cancer chemotherapy. It was discovered that it acts by inhibiting the DNA synthesis in leukemic cells (31). Moreover, it was demonstrated that the nucleoside analog can even be incorporated into the DNA, a finding that might explain the teratogenic and mutagenic potential of this drug. In parallel, it was demonstrated that ara-C is intracellularly phosphorylated to ara-CTP, a nucleotide that acts as a strong competitive inhibitor for mammalian DNA polymerases (32).

Arabinofuranosyl adenine: A further boost to the arabinofuranosyl nucleosides as therapeutically important drugs was provided by the studies on ara-A. After having identified and isolated the herpes simplex virus (HSV) coded DNA polymerase (33), it was possible to demonstrate that this viral enzyme is strongly and competitively inhibited by the triphosphate derivative of ara-A (34) (Fig. 4C). The degree of inhibition can be quantitated by calculating the ratio between the $K_{m}$ value (Michaelis constant) and the $K_{i}$ value (inhibitor constant). The $\mathrm{K}_{\mathrm{m}}: \mathrm{K}_{\mathrm{i}}$ values in the assays with dATP and araATP for the cellular polymerases ( $\alpha$ and $\beta$ ) as well as the Rous sarcoma virus DNA polymerase are low (in the range of 1 to 2). However, HSV DNA polymerase is inhibited with a ratio close to 100 , indicating the high degree of selectivity of this nucleoside analog. Based on this and subsequent studies, araA was introduced worldwide for anti-HSV treatment as Vidarabin (Germany), Vira-A (USA), Vidarabine (China), Arasena-A (Japan) or Vira-MP (France). In Japan, ara-A is the most frequently applied ointment against herpes simplex virus infection (Arasena- $\mathrm{A}^{\circledR}$ [Mochida Pharmaceutical Co, Tokyo]). The major reason for this success was the fact that the bioactive compound ara-A can be synthesized in unlimited amounts.

\section{Cytostatic and Anti-inflammatory Secondary Metabolite: Avarol/Avarone}

After the discovery that isoprene (2-methylbutadiene) is the building block of terpenes (35), it was found 30 years ago that isoprenoids are among the most diverse secondary metabolites in sponges (36). Perhaps, the most extensively studied sesquiterpenoid is the hydroquinone avarol and its quinone avarone. These secondary metabolites were isolated from the sponge Dysidea avara by Minale (37) and De Rosa (38). Its biological activity as a cytostatic/anti-leukemic compound was described (39) and its anti-HIV activity (human immunodeficiency virus type 1) was also established (40). The latter result was confirmed by several studies $(41,42)$. Finally, it was established that the compound displays anti-inflammatory activity 
A
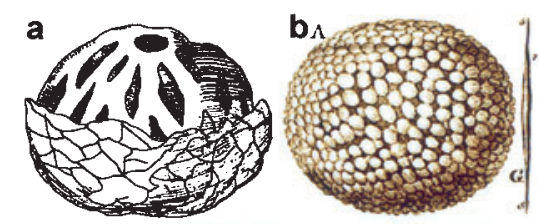

c

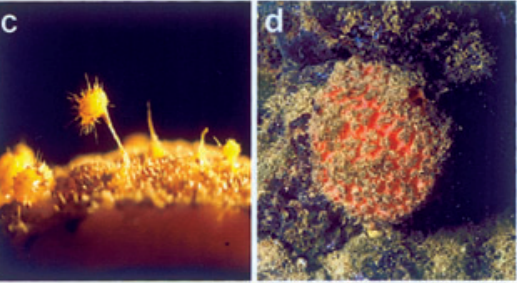

B

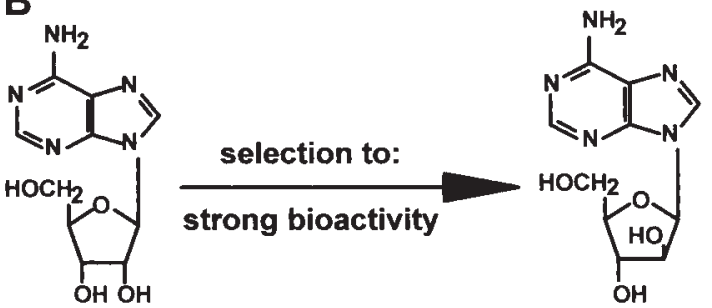

adenosine

ara-A

C

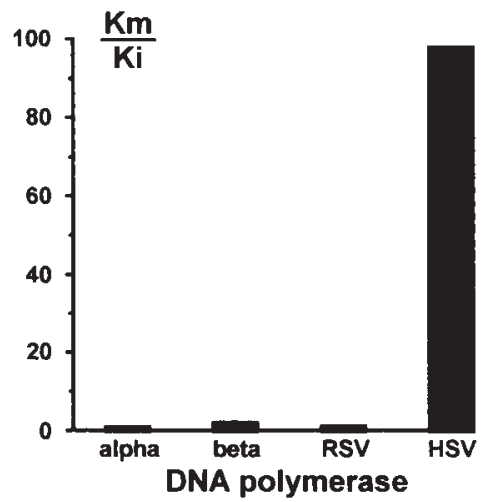

Figure 4. Arabinofuranosyl cytosine. (A) Sponges of the genus Tethya (Demospongiae) - views from the past and the present. (Aa) a sketch of this sponge by Gesner (1558); (Ab) a picture of Tetia sphaerica (Donati 1753); (Ac) Tethya lyncurium or Tethya aurantium with its protruding buds $[\times 3]$; (Ad) Tethya limski, an endemic species from the 'Limski Canal' (Rovinj; Croatia) $[\times 0.5]$. (B) Evolutionary shaping (evochemistry) of a normal metabolite (adenosine) into a bioactive secondary metabolite (ara-A) in the sponge Cryptotethya crypta during over 500 million years of biochemical selection for the highest potency in action and selectivity in function. (C) Mode of action of ara-A. This nucleoside analog in its triphosphorylated form competitively inhibits the herpes simplex virus (HSV) coded DNA polymerase. The ratio of the Michaelis constant $\left(\mathrm{K}_{\mathrm{m}}\right)$ and the inhibitor constant $\left(\mathrm{K}_{\mathrm{i}}\right)$ reflects the efficacy of this inhibitor on HSV polymerase.

(43). Clinical trials were initiated; but had to be stopped primarily due to the shortage of starting material.

Based on the awareness that secondary metabolites from sponges have a chance to be applied for human benefit in a wider sense only if a sustainable exploitation is guaranteed, intense efforts have been undertaken to produce these secondary metabolites in a bioreactor. With the establishment of the primmorph system, it became-although not yet in a satisfactory manner-likely that sponge metabolites can be produced by cell culture in vitro (44).

\section{Modulation by Fungal Components: Aeroplysinin}

From the Mediterranean sponge Verongia (Aplysina) aerophoba (Fig. 5), the brominated metabolite-aeroplysinin (Fig. 5) — was isolated (45), which displays antibacterial (45) and anti-tumor activity (46). Interestingly, aeroplysinin acts as an anti-angiogenic compound in the chick embryo system (47). Cell biological studies with the sponge confirmed that the compound is synthesized by the sponge itself and not by symbiotically associated bacteria (48).

As originally shown in the mammalian system (49), aeroplysinin was also recently demonstrated to cause inhibition of tyrosine kinase in the sponge $S$. domuncula (3). Relevant to the understanding of how the sponges detect potential parasitic or symbiotic microorganisms was the finding that $S$. domuncula contains a cell surface receptor, which recognizes $(1 \rightarrow 3)-\beta-D-$ glucan, a carbohydrate indicative of fungi. The expression of the $(1 \rightarrow 3)$ - $\beta$-D-glucan binding protein receptor could be blocked by aeroplysinin. Further, the genes coding for the downstream proteins in the signal response circuit, the fibrinogen-like protein and the epidermal growth factor (EGF)-precursor proteins were modulated in response to aeroplysinin treatment (Fig. 5). It could be concluded that the $(1 \rightarrow 3)-\beta$-D-glucan-recognizing receptor controls, after binding of the ligand, the expression of a protein involved in the recognition of fungi (fibrinogen), and of a cytokine that modulates cell proliferation (EGF) (Fig. 5).

\section{Induction of Apoptosis: Sorbicillactone A}

As outlined earlier, sponges have developed strategies to defend themselves against foreign organisms - prokaryotic, eukaryotic or viral attackers - by the production of secondary metabolites that repel them $(21,50)$. It is known that some potent antimicrobial compounds, especially antibiotics, are produced by microorganisms such as bacteria (e.g., Streptomyces) and fungi ('Fungi imperfecti', e.g., Penicillium). Consequently, and teleologically speaking, sponges have utilized the capability of these microorganisms as symbionts to enhance their potency to synthesize bioactive compounds.

Several efforts have been undertaken to cultivate the symbionts - in this case, fungi- that are associated with sponges. In the course of this research, different fungal strains were isolated from Mediterranean sponges and tested for bioactivity. Among the activities, the novel compound sorbicillactone A (Fig. 6B), which was recently isolated at the Center of Excellence 'BIOTECmarin' from a strain of fungus Penicillium chrysogenum (14), was characterized (Fig. 6A). P. chrysogenum was obtained from a sample of the Mediterranean sponge Ircinia fasciculata; sorbicillactone A possesses a unique bicyclic lactone structure, which appears to be derived from sorbicillin. Among the numerous known sorbicillin-derived structures, it is the first to contain nitrogen and thus, the first representative of a novel type of 'sorbicillin alkaloids'. This compound exhibits promising activities in several mammalian and viral test 


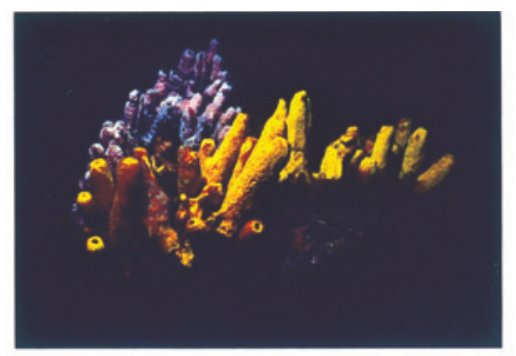<smiles>CCC1(O)C=C(Br)C(OC)=C(Br)C1O</smiles>

Aeroplysinin-1

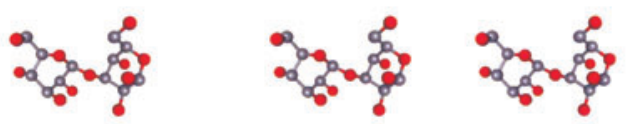

$(1,3)-\beta-D-g l u c a n$

$(1,3)$

,3)- $\beta$-D-glucan
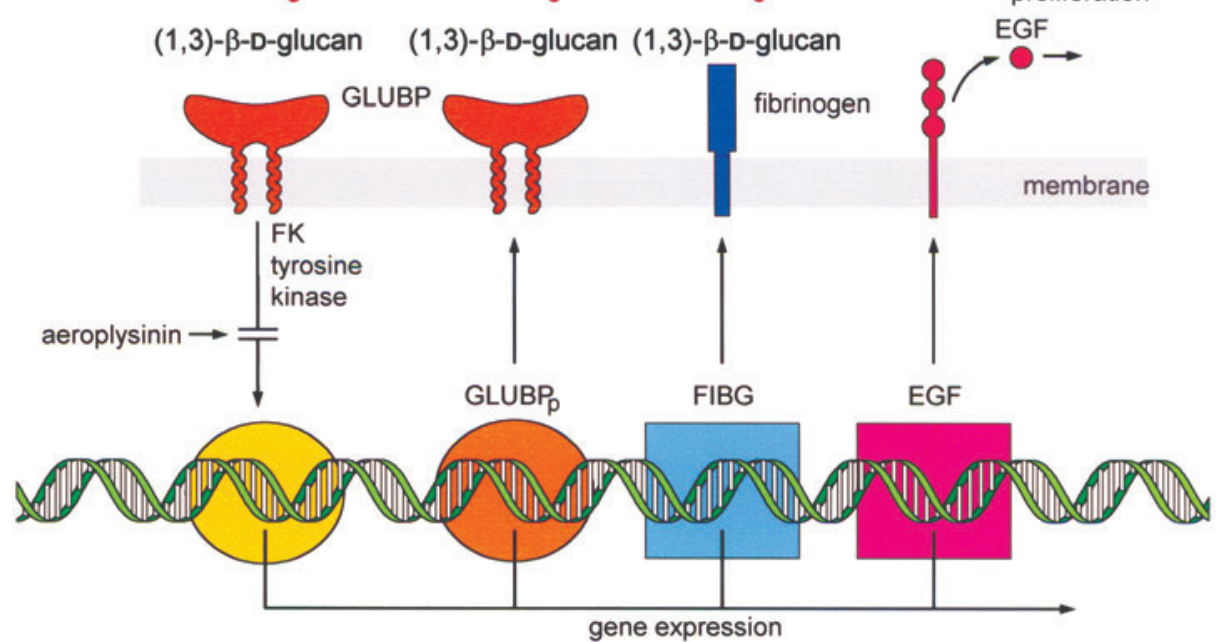

Figure 5. Aeroplysinin. The Mediterranean sponge Verongia aerophoba (left) produces the secondary metabolite aeroplysinin (right). This tyrosine kinase inhibitor modulates the recognition system of sponges for fungi. The fungal model compound curdlan, composed of $(1 \rightarrow 3)$-b-D-glucan, interacts with its receptor, the $(1 \rightarrow 3)-\beta$-D-glucan binding protein (GLUBP), in the $S$. domuncula system. Controlled by a tyrosine kinase, which can be inhibited by the aeroplysinin, this recognition results in an expression of three genes: one coding for the glucan binding protein precursor (GLUBPp), the second for the fibrinogen-like protein (FIBG) and the third for the epidermal growth factor (EGF)-precursor. While fibrinogen is assumed to be involved in the recognition of fungi, EGF might be involved in the control of proliferation of sponge cells.

systems. It is highly selective in its cytostatic activity against murine leukemic lymphoblasts (L5178y) (Fig. 6C).

Recently, it was also established that the mode of action of sorbicillactone $\mathrm{A}$ is through the induction of apoptosis in leukemic cells. This finding, together with the selective inhibition of tumor cells, may qualify sorbicillactone A (or one of its derivatives) for animal and (hopefully) also future therapeutic human trials. The potential applicability is further supported by our success in upscaling the production of this natural product from amounts less than a milligram to a scale above $50 \mathrm{~g}$; this method could be developed in only 3 months and was directed by Profs $G$ Bringmann (Würzburg) and JF Imhoff (Kiel) at the Center of Excellence. Crystals of sorbicillactone A are shown in Fig. 6D.

Interestingly, sorbicillactone A displays no effect on sponge cells, as tested with $S$. domuncula.

\section{Inhibition of Angiogenesis: 2-methylthio-1,4- napthoquinone}

Molecular biological studies have provided compelling evidence that sponges share basic receptor/ligand systems, especially those involved in body plan formation and in immune recognition, with the higher metazoan phyla. An established in vitro cell/organ-like culture system from sponges, the primmorphs, comprises proliferating and differentiating cells, but not the typical canals of the aquiferous system.

Recently, we succeeded in transferring the primmorphs from the demosponge $S$. domuncula to a homologous matrix (galectin), in order to induce the formation of canal-like structures in these 3D-cell aggregates. In parallel with the formation of the canals, a gene is expressed whose deduced protein falls into the CD36/LIMPII receptor family. We cloned the receptor and found that it is strongly expressed after adhesion of primmorphs to the galectin matrix. This process could be suppressed if primmorphs were co-incubated with a homologous polypeptide containing the CSVTCG domain, that was until recently found only in thrombospondin-1 (and related) molecules of vertebrates. In situ hybridization studies revealed that the $S$. domuncula CD36/LIMPII receptor is localized in the pinacocytes, the cells that surround the canals in sponges.

Furthermore, a secondary metabolite, 2-methylthio-1,4napthoquinone (MTN), was isolated and characterized from a sponge-associated bacterium. MTN causes inhibition of cell proliferation of vertebrate tumor cells at concentrations 
of $>80 \mathrm{ng} / \mathrm{ml}$. However, only doses of $2 \mathrm{mg} / \mathrm{ml}$ are required to potently inhibit angiogenesis in the chick chorioallantoic membrane assay. This compound was also found to suppress the expression of the $S$. domuncula CD36/LIMPII at concentrations of $10 \mathrm{ng} / \mathrm{ml}$; this result is the first indication that this secondary metabolite comprises a conserved functional activity, the suppression of the formation of the circulation system, from sponges to vertebrates (6).

\section{Immune Modulating Activity: FK506}

Another bioactive compound that causes the same biological/therapeutic effect in sponges and also in humans is worth mentioning. The background in this case is that molecular and functional data indicate that sponges possess molecules similar to and homologous with those of the innate and adaptive immune systems of higher metazoa (51).

Applying the biological system of parabiosis and the technique of differential display of mRNA, two sponge cDNAs encoding putative FK506-binding proteins have been isolated. This finding was interesting, since FK506 is successfully applied in clinics as a drug to prevent allograft rejection. This secondary metabolite was found to be toxic to $S$. domuncula cells in vitro at doses above $100 \mathrm{ng} / \mathrm{ml}$. Autograft fusion of transplants from $S$. domuncula was not affected by FK506. Allograft non-fusion was not affected by FK506 at toxic doses; however, at the non-toxic dose of $20 \mathrm{ng} / \mathrm{ml}$, the allografts fused with each other. It has been demonstrated that at the attachment zone in untreated (especially drastic) and in FK506-treated allografts, the expression of the genes encoding the FK506binding proteins is upregulated. These data indicate that the drug FK506 suppresses allograft rejection in S. domuncula most probably via interaction with the expression of the gene coding for the FK506-binding proteins (52).

On the basis of these data, we propose that sponges possess the key pathways for the disease control observed in mammals and present day species, and respond to drugs successfully used to treat disorders in higher mammals.

\section{Bacterial Gene Cluster}

Sponges are (always) associated with bacteria; most of them are known to produce polyketides, e.g., swinholide produced by the lithistid sponge Theonella swinhoei (53), a class of compounds that display highly potent (especially) antibiotic activities. However, most of the bacteria present in sponges are considered to be non-culturable. To exploit the bioactive potential of these microorganisms, molecular biotechnological techniques must be developed. One promising approach is to clone the polyketide synthases, which synthesize the core of the bioactive compound, and to express them in a heterologous system. In the course of this attempt, polyketide synthases have been isolated from the bacteria of the sponge $S$. domuncula (54); the length is approximately $40 \mathrm{~kb}$. The polyketide synthases are multienzyme complexes that use simple organic building blocks, e.g., acetyl-CoA and their derivatives. As represented schematically in Fig. 7B, the polyketide synthases comprise at least the following enzymic activities: $\beta$-keto

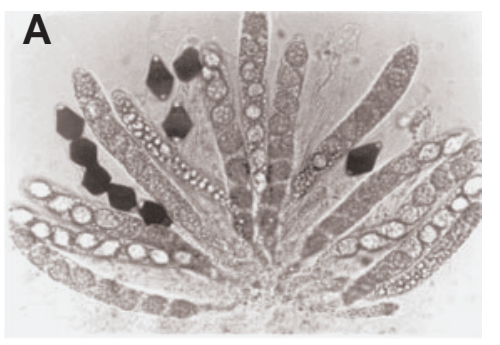

B<smiles>C/C=C/C=C/C(O)=C1/C(=O)C(C)=C(O)C2(C)OC(=O)C(C)(NC(=O)/C=C/C(=O)O)C12C</smiles>

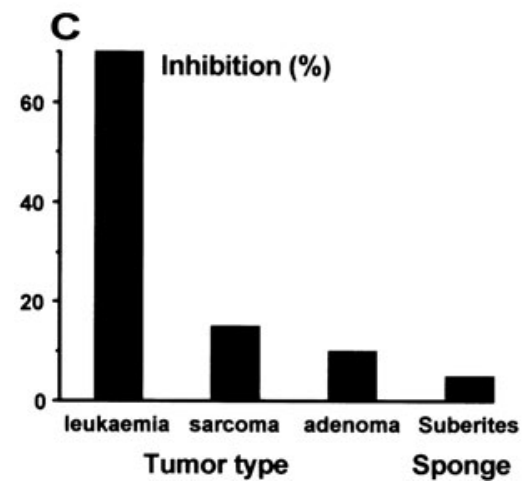

D Sorbicillactone A

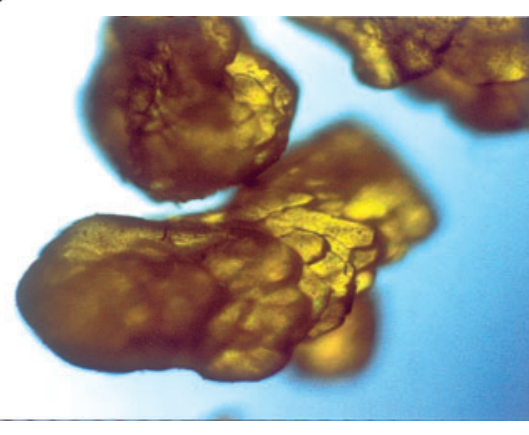

Figure 6. Sorbicillactone A. (A) This secondary metabolite is synthesized by the sponge-associated fungus, Biconiosporella corniculata Schaumann (Ascomycota). (B) Structure of sorbicillactone A. (C) Inhibitory activity of $0.4 \mu \mathrm{g} / \mathrm{ml}$ of sorbicillactone A on murine leukemic lymphoblasts L5178y (leukaemia), human cervix HeLa S3 cells (sarcoma) and rat adrenal phaeochromocytoma cells PC-12 (adenoma). The inhibitory activity of the compound on the respective tumor cell lines is given in percentage. In parallel, the inhibition of sorbicillactone A was tested against $S$. domuncula cells, which remained almost non-affected (D) Crystals of sorbicillactone A, after having upscaled the production of this natural product to amounts in grams (courtesy Dr G Bringmann, Würzburg). 


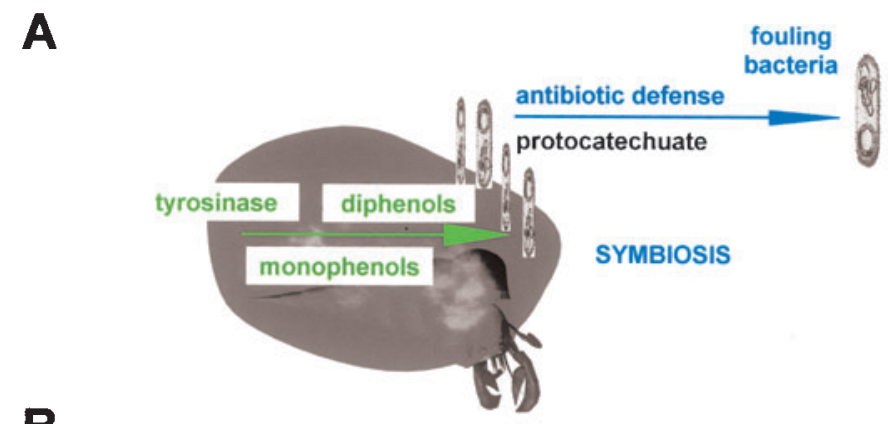

B

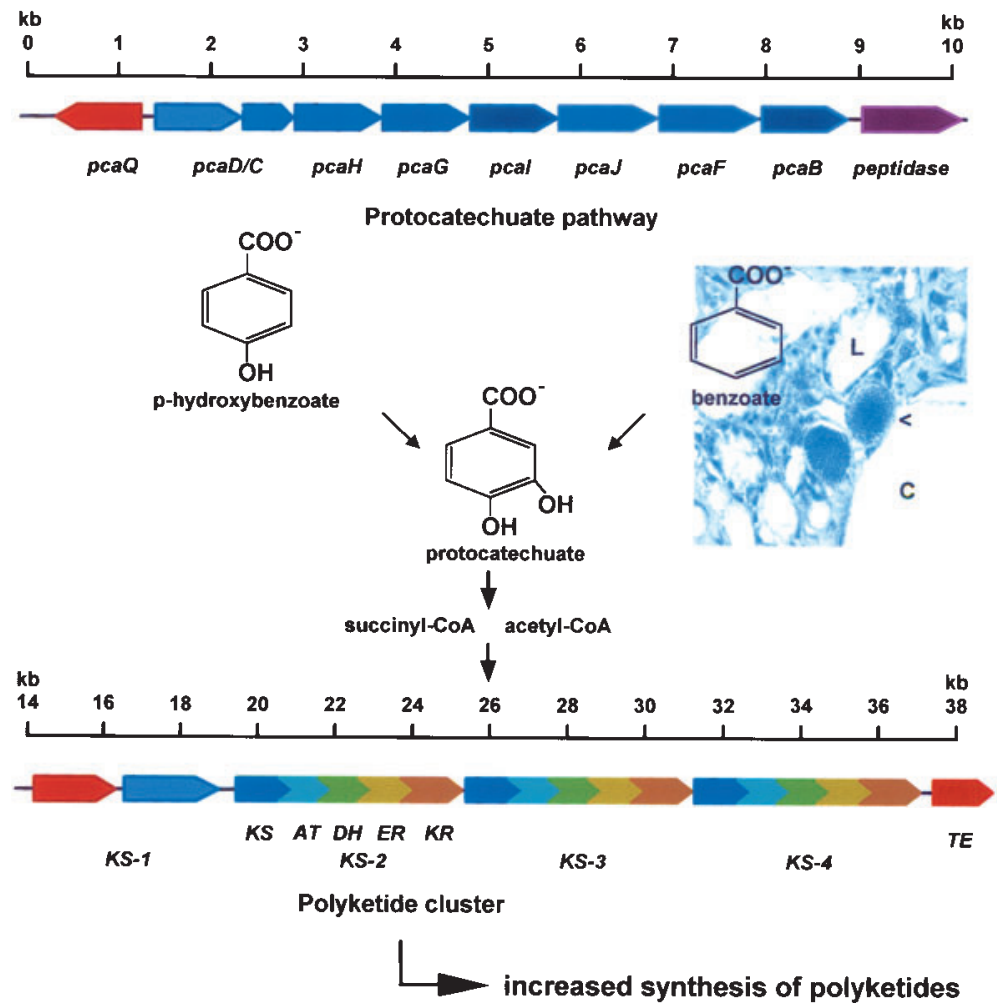

Figure 7. Sponge-bacteria relationship. (A) Formation of diphenols from monophenols mediated by the sponge enzyme tyrosinase. The reaction product(s) is taken up by surface-associated bacteria and used as carbon source. (B) Schematic model of the domains encoding the polyketide synthase (KS) cloned from a bacterium that had been isolated from the sponge $S$. domuncula (the scales indicate the stretches on the DNA [given in $\mathrm{kb}$ ]). Lower scheme: the modular polyketide synthase is composed of at least the following enzymic activities: $\beta$-keto acylthioester synthase (KS), acyltransferase (AT), ketoacyl-reductase (KR), dehydratase (DH), enoyl reductase (ER) and thioesterase domain (TE). Multiple copies of active site units (in this case, KS-1 to KS-4) are usually present. The photograph at the center of the figure shows a semi-thin section through the mesohyl compartment adjacent to the lacunae, which are surrounded by an epithelium (formed by endopinacocytes). One bacteriocyte (arrow head) is shown, which is embedded in the epithelium that surrounds a water canal (C); it is almost completely filled with bacteria (light micrograph; $[\times 250])$. Upper scheme: upstream of the polyketide synthase cluster of this sponge-associated bacterium, genes encoding for enzymes of the protocatechuate/ $\beta$-ketoadipate pathway have been identified (abbreviated as $p c a B-p c a Q$ ). This pathway uses benzoate or $p$-hydroxybenzoate and forms succinyl-CoA and acetyl-CoA in the cascade, metabolites that also enter the polyketide synthase cycle. This pathway is used by the sponge-associated bacteria to utilize the carbon source. acylthioester synthase, acyltransferase and acyl carrier protein domain (55). In addition, other enzymic activities may be included, e.g., ketoacyl-reductase, dehydratase, enoyl reductase and thioesterase domains. Multiple copies of active site units reminiscent of those of the fatty acid synthases exist.

Since almost all marine demosponges contain bacteria, the benefit of such an association needs to be investigated. First, data are now available that provide an insight into the molecular mechanism by which the host (sponge) might discriminate between symbiotic or commensalic and parasitic bacteria. Some of these symbiotic bacteria produce secondary metabolites. It is worth mentioning the recently obtained data as an example of the biochemical basis of a symbiotic relationship between bacteria and the sponge host. It could be demonstrated that under optimal aeration conditions, $S$. domuncula expresses the enzyme tyrosinase, which synthesizes diphenols from monophenolic compounds (56). A cell surface "nonculturable' bacteria (SB2) can be detected simultaneously with this increased expression. The SB2 bacteria are known to produce bioactive compound(s). The protocatechuate gene cluster was cloned and sequenced from this SB2 bacterium. This cluster comprises all genes coding for enzymes involved in the conversion of protocatechuate to acyl-CoA. The expression is strongly induced if the bacteria are cultivated on M9/protocatechuate medium. We concluded that metabolites, in this case, diphenols, produced by the sponge $S$. domuncula, are utilized by the sponge surface-associated bacterium for energy generation. This approach will help further to uncover the symbiotic pathways between sponges and their associated 'non-culturable' microorganisms (Fig. 7A).

\section{Selected Bioactive Compounds: Bioactive Proteins}

Until recently, no conclusive data were available to ascertain which bacterial strains are symbiotic and which are parasitic. 
Experimental data are now available to gain a preliminary understanding of the molecular mechanism by which the host (sponge) might discriminate between symbiotic or commensalic and parasitic bacteria. Certain bacterial strains can be engulfed by specific sponge cells, the bacteriocytes (57), and protein synthesis in tissue from $S$. domuncula is inhibited after incubation with the bacterial endotoxin lipopolysaccharide (LPS) (57).

An effective mechanism to eliminate microbes is intracellular digestion. This cellular defense mechanism against foreign invaders is well developed in organisms ranging from sponges to insects and humans. Sponges possess specialized amoeboid cells, the archaeocytes, which have in the past been regarded as the macrophages of sponges. Molecules involved in cellular and humoral immunity have been isolated and functionally analyzed in S. domuncula (4). Some molecules that are toxic for pro- and eukaryotic non-self organisms are mentioned here.

\section{Antibacterial Activity: Pore-forming Protein}

A cDNA clone was isolated from $S$. domuncula that resembles human perforin; it displayed antibacterial activity (11). Human perforin is found in lytic granules of cytotoxic natural killer and $\mathrm{T}$ cells. After release, perforin forms pores in the target cell membranes, initiating osmotic lysis. Hence, perforin is an effector molecule of the non-specific cytotoxic T lymphocytemediated defense system of mammalians. The recombinant perforin protein from S. domuncula was prepared and found to display antimicrobial activity. In an earlier study on the sponge Tethya lyncurium, a pore-forming protein had been described, which resembles other pore-forming toxins in size, e.g., the E. coli hemolysin (17).

\section{Antibacterial Activity: Tachylectin (a S. domuncula Lectin)}

Another bioactive protein from a sponge worth mentioning here is tachylectin (16). Recently, we have demonstrated the existence of a tachylectin-related protein in $S$. domuncula, which we termed Suberites lectin (tachylectin). In response to lipopolysaccharide (LPS) treatment of primmorphs, the mitogenactivated protein kinase pathway is activated; this process is abolished by the monosaccharide N-acetyl-D-glucosamine (D-GlcNAc). The cDNA encoding the $S$. domuncula lectin was identified and cloned. The steady state level of expression of the Suberites lectin rises in primmorphs in response to LPS, an effect that was prevented by co-incubation with D-GlcNAc. We purified the natural sponge lectin by affinity chromatography; it has a size of $27 \mathrm{kDa}$ and displays antibacterial activity against the gram-negative Escherichia coli and the grampositive Staphylococcus aureus. The putative protein, deduced from the cloned gene, was identical/similar to the natural protein, as demonstrated by immunological cross-reactivity with specific antibodies. We conclude that the $S$. domuncula lectin acts as an antibacterial molecule involved in immune defense against bacterial invaders.

\section{Unique Biomaterials in Sponges: Silica}

Among the metazoan phyla, primarily sponges, more specifically the Demospongiae and Hexactinellida, contain a skeleton that is composed of hydrated, amorphous and non-crystalline silica. This inorganic material is deposited in the spicules, their major skeletal elements (58) (Fig. 8). In 1859 (59), the first publication on sponges, the freshwater sponge Spongilla fluviatilis appeared as a model in which detailed analyses on the development and differentiation of fertilized eggs were provided. Even the differentiation stages of the sponge cells, e.g., from the 'Schwärmsporen' to the spicule-forming sclerocytes were described in detail (Fig. 8Aa). Similarly, a few years later, DeLage (60) precisely observed that the spicules are formed intracellularly (Fig. $8 \mathrm{Ab}$ ). It is notable that he mentioned that the spicule-containing cell 'est de même nature que les amoeboïdes'. This remark can also be considered as an indication that he had been aware of the new concept of stem cells that originated at this time (61).

In the past few years, silicate metabolism in sponges has been elucidated to some extent (62). The formation of the spicules is a rapid process; in the freshwater sponge Ephydatia fluviatilis, the 100-300 $\mu \mathrm{m}$ long spicules are synthesized under optimal conditions within $40 \mathrm{~h}$. The rate of appearance of the new spicules is correlated with the growth of the oscular tube, implying that an efficient relocation system must be active in order to place the spicules at their functional destination. In addition, reorganization and disorganization processes in sponges, such as the bud formation, require an efficient machinery to replace spicules. The shape and growth forms of the spicules are incredibly multiform and fascinating. In this paper, samples from the glass sponge (Hexactinellida) Hyalonema sieboldi are presented. The $300 \mathrm{~mm}$ long basal spicules (Fig. 8B) are compactly bundled and intricately twisted. On this basal tuft, the sponge body is placed, which appears as a raised hide. Scanning electron microscopy reveals that the large basal spicules are built by concentric layers of silica. These layers are characterized by glass of varying refractive indices (Fig. 8Ba and b). Owing to this unique structure, the spicules can transmit light through their silica skeleton (Fig. 8C).

Needless to mention, biosilica has a wide range of applications in the medical field, from novel biomaterials for bone replacements to the stabilization of the tissue.

\section{Anabolic Enzyme for the Synthesis of Silica: Silicatein}

The enzyme silicatein from Demospongiae has been described, and it polymerizes silicon alkoxide substrates to silica $(62,63)$. It could be demonstrated in the primmorph system from $S$. domuncula that spicule formation is genetically controlled. In primmorphs, silicon-responsive genes, e.g., silicatein, collagen and myotrophin, are upregulated if the primmorphs are grown at $60 \mu \mathrm{M}$ silicate. A pathway could be proposed by which the spicules are formed in sclerocytes in concert with the expression of myotrophin and collagen in lophocytes and/or spongocytes. Furthermore, it was reported 

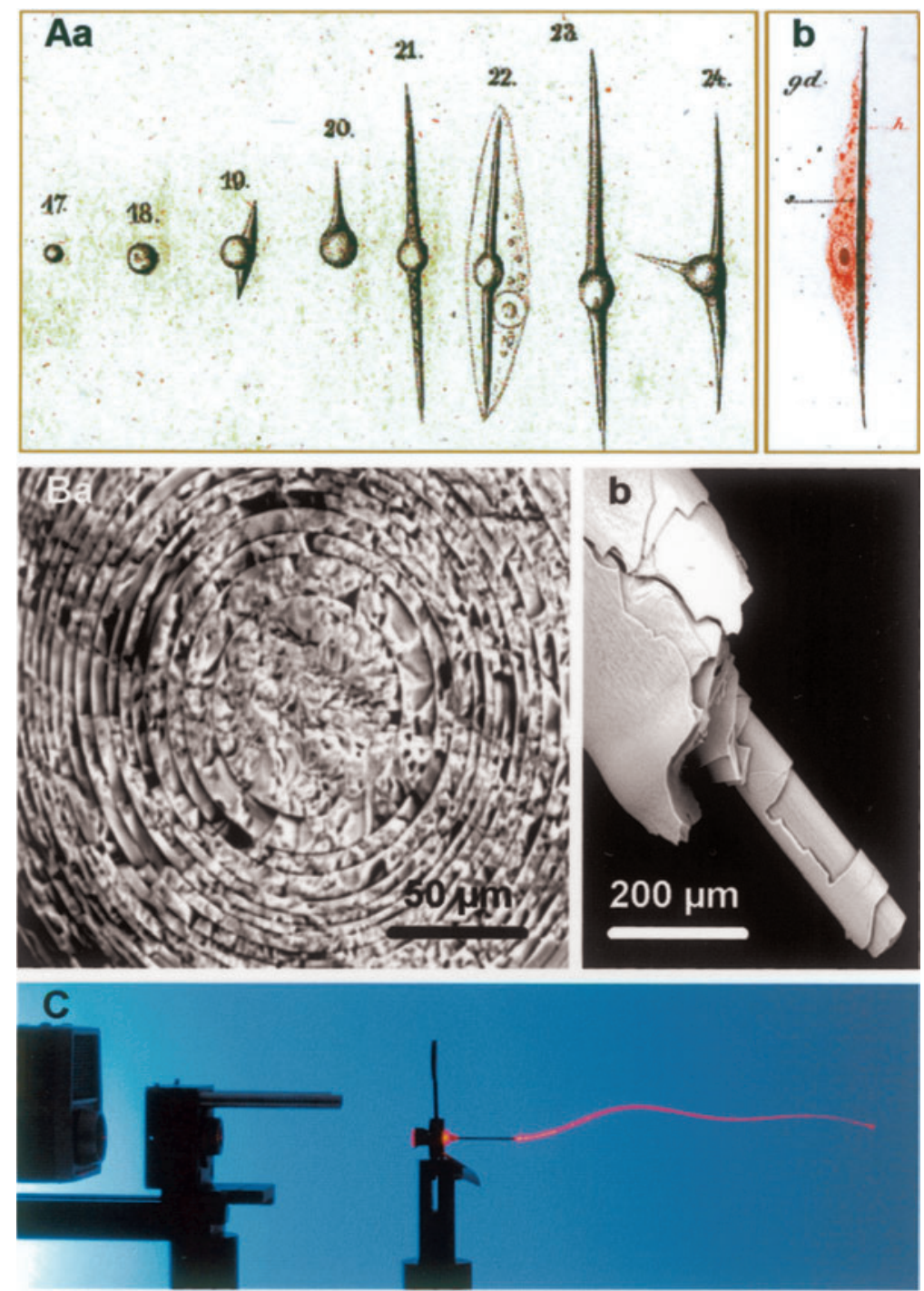

Figure 8. Spicules from siliceous sponges. (A) (Aa) Differentiation of embryonic 'Schwärmsporen' into differentiated spicule-forming sclerocytes (in Spongilla fluviatilis) (59). (Ab) The intracellular formation of the spicules was also precisely observed by DeLage (60). (B) Scanning electron microscopic analysis of basal spicules (Ba: cross section; Bb: side view) from Hyalonema sieboldi showing the concentric silica layers that constitute them. (C) Use of one basal spicule from H. sieboldi as a light conductor. A laser beam is directed at one end of a spicule through which the light is transmitted to the other end.

that the size of primmorphs drastically increased if they were cultivated in iron-containing medium, indicating that $\mathrm{Fe}^{3+}$ ions are required for the proliferation of cells in primmorphs from S. domuncula. In parallel, $\mathrm{Fe}^{3+}$ induces the expression of ferritin and potently stimulates the synthesis of spicules. This result is supported by the finding that the enzymic activity of silicatein-converting organosilicon to polymerized silicic acid-depends on $\mathrm{Fe}^{3+}$. Moreover, the expression of a scavenger receptor molecule, possibly involved in the morphology of spicules, depends on the presence of $\mathrm{Fe}^{3+}$. We conclude that iron is an essential factor in proliferative and morphogenetic processes in primmorphs of sponges.

\section{Catabolic Enzyme: Silicase}

In the course of further elucidating the metabolism of siliceous spicules in Demospongiae, another enzyme, silicase, was identified from the marine sponge $S$. domuncula; silicase can depolymerize amorphous silica. Using the 'differential display' technique of transcripts, one cDNA was identified that encodes a carbonic anhydrase-like enzyme, the silicase. The deduced polypeptide is 379 aa long and is very similar to the family of carbonic anhydrases. The recombinant silicase was prepared; besides a carbonic anhydrase activity, it displays the ability to dissolve amorphous silica under the formation of free silicic acid. To support the results from the 'differential display', Northern blot studies were performed. They revealed that after incubation of cells/tissue from $S$. domuncula, the expressions of the genes encoding the catabolic enzyme silicase as well as the anabolic enzyme silicatein increased (64).

\section{Biomedical Potential}

The need for silica as a starting source for biomedical applications is huge and ranges from the coating of artificial bones to 
the implants of xenogeneic and allogeneic tissues. The findings that the spicules of sponges are both enzymatically synthesized (using the enzyme silicatein) and enzymatically degraded (using the enzyme silicase) hints at applications in biotechnology that are yet to be quantified, ranging from the potential use of silicon-based materials in optics and electronics to biomedicine.

Equally promising are the results obtained with the calcareous skeleton from corals. It comprises a similar suitable matrix. For example, the use of coral granules in alveolar ridge preservation first stabilizes the bone defects and is subsequently replaced (65). In a straightforward study implementing modern molecular biological and cell biological techniques, it could be demonstrated that if coral samples are combined with recombinant human bone morphogenetic protein-2 (rhBMP2 ), the new matrix thus obtained can substitute bone in the field of orthopedics and maxillofacial surgery (66).

\section{The Future (Evochemistry) and Conclusion}

In the past, combinatory chemistry resulted in the synthesis of numerous compounds. The availability of high numbers of synthetic compounds demanded efficient high throughput screening methods and processes, which have now become available. In parallel with this development and the need for novel lead structures for new pharmacologically active drugs, there was a great demand for a multitude of extracts from natural sources, including sponges. However, this rationale is not justified since the 'quality' of the extracts from natural sources is often fundamentally distinguished from a (merely stochastically synthesized) chemical product. It should be realized that the bioactive compounds, which are synthesized in nature to protect a particular organism, had been selected from a wide variety of possibilities that allowed the intermediary metabolism, and were under the pressure of evolution for several hundreds of million years to reach optimal activity.

The consequences of a changed view and appreciation of extracts from natural sources are that-in contrast to the approach with chemicals produced by combinatory chemistry - natural extracts should not be primarily tested in a wide variety of test batteries; rather, they should be tested in a rational manner with the help offered by the biological systems from which the compounds have been extracted. Owing to the progress initiated by the pressure of the society for sustainable use of natural resources for human benefit, the exploitation of natural biodiversity became possible through the application of the techniques of molecular biology and modern cell biology.

\section{Acknowledgments}

We greatly appreciate the help of M Plenikowski for the design of some photographs. This study is supported by the Bundesministerium für Bildung und Forschung (Project: Center of Excellence BIOTECmarin) and the International Human Frontier Science Program [RG-333/96-M].

\section{References}

1. Bringmann G, Lang G, Mühlbacher J, Schaumann K, Steffens S, Rytik PG, et al. Sorbicillactone A, a structurally unprecedented bioactive novel-type alkaloid from a sponge-derived fungus. In: WEG Müller, editor. Sponges (Porifera). Marine Molecular Biotechnology. Berlin: Springer 2003; 231-53.

2. Müller WEG, Klemt M, Thakur NL, Schröder HC, Aiello A, D'Esposito M, et al. Molecular/chemical ecology in sponges: evidence for an adaptive antibacterial response in Suberites domuncula. Mar Biol 2003;144:19-29.

3. Perović-Ottstadt S, Adell T, Proksch P, Wiens M, Korzhev M, Gamulin V, et al. A $(1 \rightarrow 3)-b$-D-glucan recognition protein from the sponge Suberites domuncula: mediated activation of fibrinogen-like protein and epidermal growth factor gene expression. Eur J Biochem 2004;271:1924-1937.

4. Müller WEG, Wiens M, Adell T, Gamulin V, Schröder HC, Müller IM. Bauplan of the Urmetazoa: the basis of the genetic complexity of Metazoa using the siliceous sponges [Porifera] as living fossils. Intern Rev Cytol 2004;235:53-92.

5. Breter HJ, Grebenjuk VA, Skorokhod A, Müller WEG. Approaches for a sustainable use of the bioactive potential in sponges: analysis of gene clusters, differential display of mRNA and DNA chips. In: WEG Müller, editor. Sponges (Porifera). Marine Molecular Biotechnology Berlin: Springer 2003; 199-230.

6. Müller WEG, Thakur NL, Ushijima H, Thakur AN, Krasko A, Le Pennec $\mathrm{G}$, et al. Matrix-mediated canal formation in primmorphs from the sponge Suberites domuncula involves the expression of a CD36 receptor-ligand system. J Cell Sci 2004;117:2579-2590.

7. Donia M, Hamann MT. Marine natural products and their potential applications as anti-infective agents. The Lancet (Infect Dis) 2003;3:338-48.

8. Mayer AMS, Hamann MT. Marine pharmacology in 2000: marine compounds with antibacterial, anticoagulant, antifungal, anti-inflammatory, antimalarial, antiplatelet, antituberculosis, and antiviral activities; affecting the cardiovascular, immune, and nervous systems and other miscellaneous mechanisms of action. Mar Biotechnol 2004;6:37-52.

9. Charisius H, Hürter T. Biotech. Technol Rev 2003;9:14-23.

10. Müller WEG, Batel R, Schröder HC, Müller IM. Traditional and modern biomedical prospecting: Part-I the History. Sustainable exploitation of biodiversity (sponges and invertebrates) in the Adriatic Sea at Rovinj (Croatia). Evid Based Complement Alternat Med 2004;1:71-82.

11. Thakur NL, Hentschel U, Krasko A, Anil AC, Müller WEG. Antibacterial activity of the sponge Suberites domuncula and its primmorphs: potentia basis for chemical defense. Aquatic Microbiol Ecol 2003;31:77-83.

12. Richelle-Maurer E, Gomez R, Braekman JC, Van de Vyver G, Van Soest RWM, Devijver C. Primary cultures from the marine sponge Xestospongia muta (Petrosiidae, Haplosclerida). J Biotechnol 2003;100:169-76.

13. Pettit GR, Knight JC, Collins JC, Herald DL, Young VG. Antineoplastic agent 430 isolation and structure of cribostatins 3, 4 and 5 from the Republic of Maldives Cribrochalina sp. J Nat Prod 2000;63:793-8.

14. Bringmann G, Lang G. Full absolute stereostructures of natural products directly from crude extracts: the HPLC-MS/MS-NMR-CD 'triad'. In WEG Müller, editor. Sponges (Porifera). Marine Molecular Biotechnology Berlin: Springer 2003; 89-116.

15. Wiens M, Luckas B, Brümmer F, Ammar MSA, Steffen R, Batel R, et al. Okadaic acid: a potential defense molecule for the sponge Suberites domuncula. Mar Biol 2003;142:213-23.

16. Schröder HC, Ushijima H, Krasko A, Gamulin V, Schütze J, Müller IM, et al. Emergence and disappearance of an immune molecule, an antimicrobial lectin, in basal Metazoa: the tachylectin family. J Biol Chem 2003;278: 32810-7.

17. Mangel A, Leitao JM, Batel R, Zimmermann H, Müller WEG, Schröder HC. Purification and characterization of a pore-forming protein from the marine sponge Tethya lyncurium. Eur J Biochem 1992;210:499-507.

18. Clare AS, Rittschof D, Gerhart DJ, Hooper IR, Bonaventura J. Antisettlement and narcotic action of analogues of diterpene marine natural product antifoulants from octocorals. Mar Biotechnol 1999;1:427-36.

19. Bergh O, Borsheim KY, Bratbak G, Heldal M. High abundance of viruses found in the aquatic environments. Nature 1989;340:467-8.

20. Gonzales JM, Moran MA. Numerical dominance of a group of marine bacteria in the alpha-subclass of the class Proteobacteria in coastal seawater. Appl Environ Microbiol 1997;63:4237-42.

21. Sarma AS, Daum T, Müller WEG. Secondary metabolites from marine sponges. Akademie gemeinnütziger Wissenschaften zu Erfurt. Berlin: Ullstein-Mosby Verlag, 1993.

22. Faulkner DJ. Marine natural products. Nat Prod Rep 2000;17:7-55. 
23. Schröder HC, Grebenjuk VA, Binder M, Skorokhod A, Batel R, Hassanein H, Müller WEG. Functional molecular biodiversity: assessment of the immune status of two sponge populations (Suberites domuncula) on the molecular level. Mar Ecol 2004 (in press).

24. Müller W, Zahn RK. Tethya limski n.sp, eine Tethyide aus der Adria (Porifera: Homosclerophorida: Tethyidae). Senckenbergiana Biol 1968; 49:469-78.

25. Müller I, Zahn RK, Zahn G, Rijavec M, Batel R, Kurelec B, et al. Description of Geodia rovinjensis n.sp. on the basis of immunological and morphological criteria. Thalassia Jugoslavica 1983;19:279-83.

26. Müller WEG, Zahn RK, Rijavec M, Britvic S, Kurelec B, Müller I. Aggregation of sponge cells. The aggregation factor as a tool to establish species. Biochem Syst Ecol 1979;7:49-55.

27. Bergmann W, Feeney RJ. Contribution to the study of marine sponges. 32 . The nucleosides of sponges. J Org Chem 1951;16:981-7.

28. Gesner C. Historiae Animalium. Vol. 20. Zürich: C Forer 1558.

29. Donati V. Auszug seiner Natur-Geschichte des Adriatischen Meers. Halle: CP Franckens 1753.

30. Cohen SS. Sponges, cancer, chemotherapy, and cellular aging. Perspect Biol Bed 1963;6:215-27.

31. Zahn RK, Müller WEG, Forster W, Maidhof A, Beyer R. Action of 1- $\beta$ D-arabinofuranosylcytosine on mammalian tumor cells. 1. Incorporation into DNA. Eur J Cancer 1972;8:391-6.

32. Müller WEG, Yamazaki Z, Sögtrop HH, Zahn RK. Action of 1- $\beta$-Darabinofuranosylcytosine on mammalian tumor cells. 2. Inhibition of mammalian and oncogenic viral polymerases. Eur J Cancer 1972;8:421-8.

33. Müller WEG, Falke D, Zahn RK. DNA-dependent DNA polymerase pattern in non-infected and herpes virus infected rabbit kidney cells. Arch ges Virus-forsch 1973;42:278-84.

34. Müller WEG, Zahn RK, Bittlingmeier K, Falke D. Inhibition of herpes virus DNA-synthesis by $9-\beta-\mathrm{D}$-arabinofuranosyladenosine in vitro and in vivo. Ann New York Acad Sci 1977;284:34-48.

35. Wallach OV. Zur Kenntniss der Terpene und der ätherischen Öle. Justus Liebigs Ann Chem 1887;239:1-54.

36. Scheuer PJ. Some marine ecological phenomena: chemical basis and biomedical potential. Science 1990;248:173-7.

37. Minale L, Riccio R, Sodano G. Avarol, a novel sesquiterpenoid hydroquinone with a rearranged drimane skeleton from the sponge Dysidea avara. Tetrahedron Lett 1974;3401-4.

38. De Rosa S, Minale L, Riccio R, Sodano G. The absolute configuration of avarol, a rearranged sesquiterpenoid hydroquinone from a marine sponge. J Chem Soc Perkin trans 1976;I:1408-14.

39. Müller WEG, Maidhof A, Zahn RK, Schröder HC, Gasic MJ, Heidemann $\mathrm{D}$, et al. Potent antileukemic activity of the novel cytostatic agent avarone and its analogues in vitro and in vivo. Cancer Res 1985;45:4822-7.

40. Sarin PS, Sun D, Thornton A, Müller WEG. Inhibition of replication of etiologic agent of AIDS by avarol and avarone. $J$ Natl Cancer Inst 1987;78:663-6.

41. Loya S, Hizi A. The inhibition of human immunodeficiency virus type 1 reverse transcriptase by avarol and avarone derivatives. FEBS Lett 1990; 269:131-4.

42. Uriz MJ, Turon X, Galera J, Tur JM. New light on the cell location of avarol within the sponge Dysidea avara (Dendroceratida). Cell Tissue Res 1996;285:519-27.

43. Ferrandiz ML, Sanz MJ, Bustos G, Paya M, Alcaraz MJ, De Rosa S. Avarol and avarone, two anti-inflammatory agents of marine origin. Eur J Pharmacol 1994;253:75-82.

44. Müller WEG, Böhm M, Batel R, De Rosa S, Tommonaro G, Müller IM, et al. Application of cell culture for the production of bioactive compounds from sponges: synthesis of avarol by primmorphs from Dysidea avara. J Nat Prod 2000;63:1077-81.

45. Fattorusso E, Minale L, Sodano G. Aeroplysinin-1, an antibacterial bromo-compound from the sponge Verongia aerophoba. J Chem Soc (Perkin 1) 1972;1:16-8.

46. Kreuter MH, Robitzki A, Chang S, Steffen R, Michaelis M, Kljajic Z, et al. Production of the cytostatic agent, aeroplysinin by the sponge Verongia aerophoba in in vitro culture. Comp Biochem Physiol 1992; 101C:183-7.
47. Rodrigues-Nieto S, Gozáles-Iriarte M, Carmona R, Munoz-Chápuli R, Medina MA, Quesada AR. Anti-angiogenic activity of aeroplysinin-1, a brominated compound isolated from a marine sponge. FASEB J 2001 (published online Dec. 28, 2001).

48. Turon X, Becerro MA, Uriz MJ. Distribution of brominated compounds within the sponge Aplysina aerophoba: coupling of X-ray microanalysis with cryofixation techniques. Cell Tissue Res 2000;301:311-22.

49. Kreuter MH, Leake RE, Rinaldi F, Müller-Klieser W, Maidhof A, Müller WEG, et al. Inhibition of intrinsic protein tyrosine kinase activity of EGFreceptor kinase complex from human breast cancer cells by the marine sponge metabolite (+)-aeroplysinin-1. Comp Biochem Physiol 1990;97B: 151-8.

50. Proksch P. Defensive roles for secondary metabolites from marine sponges and sponge-feeding nudibranchs. Toxicon 1994;32:639-55.

51. Müller WEG, Blumbach B, Müller IM. Evolution of the innate and adaptive immune systems: relationships between potential immune molecules in the lowest metazoan phylum (Porifera) and those in vertebrates. Transplantation 1999;68:1215-27.

52. Müller WEG, Steffen R, Lorenz B, Batel R, Kruse M, Krasko A, et al Suppression of allograft rejection in the sponge Suberites domuncula by FK506 and expression of genes encoding FK506-binding proteins in allografts. J Exp Biol 2001;204:2129-207.

53. Bewley CA, Faulkner DJ. Lithistid sponges: star performers or hosts to the stars? Angew Chem (Int Ed Eng) 1998;37:2162-78.

54. Müller WEG, Grebenjuk VA, Le Pennec G, Schröder HC, Brümmer F, Hentschel U, et al. Sustainable production of bioactive compounds by sponges: cell culture and gene cluster approach. Mar Biotechnol 2004 (in press).

55. Khosla C, Gokhale RS, Jacobsen JR, Cane DE. Tolerance and specificity of polyketide synthetases. Annu Rev Biochem 1994;68:219-53.

56. Müller WEG, Grebenjuk VA, Thakur NL, Thakur AN, Krasko A, Müller IM, et al. Oxygen-controlled bacterial growth in the sponge Suberites domuncula: towards a molecular understanding of the symbiotic relationships between sponge and bacteria. Appl Environ Microbiol 2004;70: 2332-41.

57. Böhm M, Hentschel U, Friedrich A, Fieseler L, Steffen R, Gamulin V, et al. Molecular response of the sponge Suberites domuncula to bacterial infection. Mar Biol 2001;139:1037-45.

58. Uriz MJ, Turon X, Becerro MA. Silica deposition in demosponges: spiculogenesis in Crambe crambe. Cell Tissue Res 2000;301: 299-309.

59. Lieberkühn N. Beiträge zur Anatomie der Spongien. Arch Anat Physiol 1859; 376-403.

60. DeLage Y. Embryogénie des éponge. Arch De Zool Exp 1892; (sér 2)10: 345-498.

61. Weismann A. Das Keimplasma: Eine Theorie der Vererbung. Jena: Fischer 1892.

62. Cha JN, Shimizu K, Zhou Y, Christianssen SC, Chmelka BF, Stucky GD, et al. Silicatein filaments and subunits from a marine sponge direct the polymerization of silica and silicones in vitro. Proc Natl Acad Sci USA 1999;96:361-5.

63. Müller WEG, Krasko A, Le Pennec G, Steffen R, Ammar MSA, Müller IM, et al. Molecular mechanism of spicule formation in the demosponge Suberites domuncula: Silicatein-collagen-myotrophin. Prog Molec Subcell Biol 2003;33:195-221.

64. Schröder HC, Krasko A, Le Pennec G, Adell T, Hassanein H, Müller IM, et al. Silicase, an enzyme which degrades biogenous amorphous silica: contribution to the metabolism of silica deposition in the demosponge Suberites domuncula. Prog Mol Subcell Biol 2003;33: 249-68.

65. Sàndor GKB, Kainulainen VT, Queiroz JO, Carmichael RP, Oikarinen $\mathrm{KS}$, Preservation of ridge dimensions following grafting with coral granules of 48 post-traumatic and post-extraction dento-alveolar defects. Dent Traumatol 2003;9:221-7.

66. Zhang S, Mao T, Meng Z, Wang H. Coral as a carrier for recombinant human bone morphogenetic protein-2. Chin Med Sci J 1999;14:125-8.

67. Krisch A. Die Fischerei im Adriatischen Meere. Pola: Carl Gerold 1900 . 


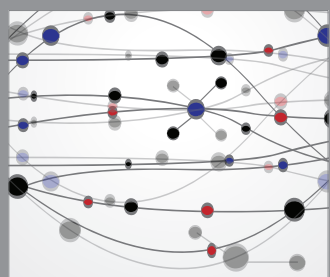

The Scientific World Journal
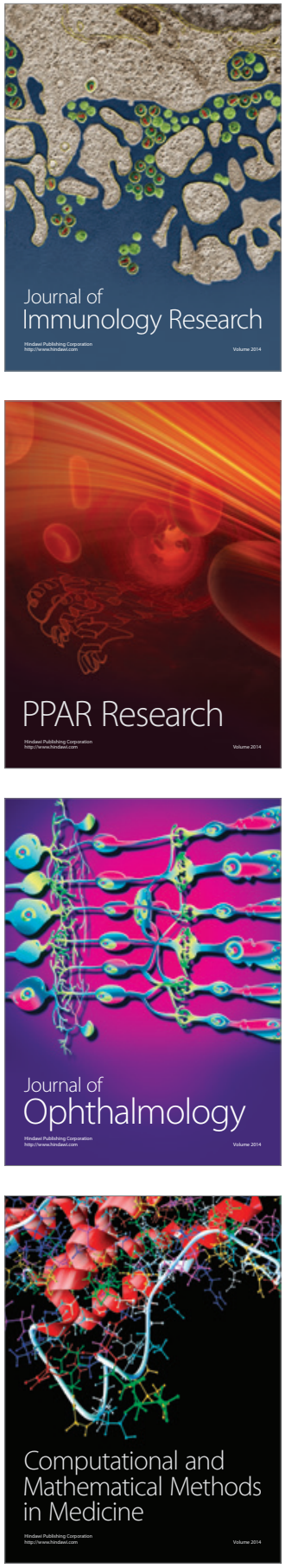

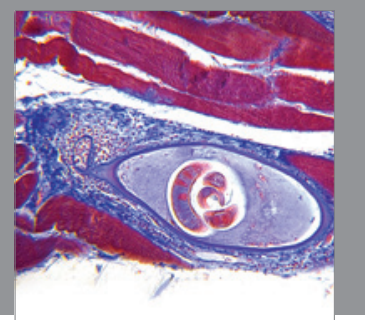

Gastroenterology

Research and Practice
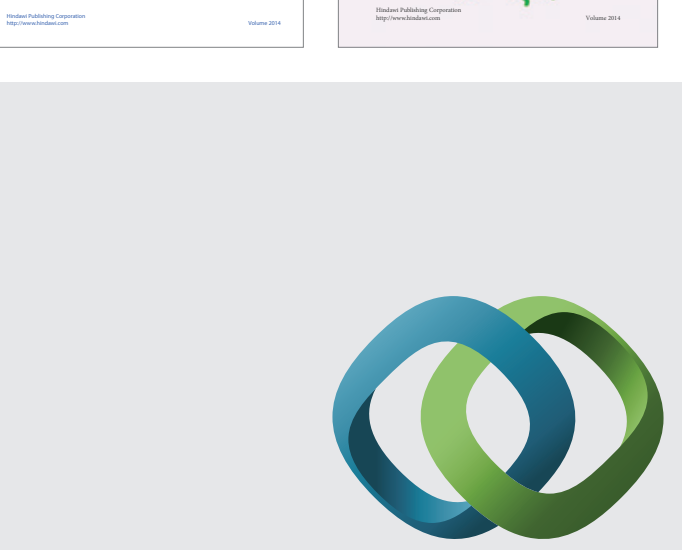

\section{Hindawi}

Submit your manuscripts at

http://www.hindawi.com
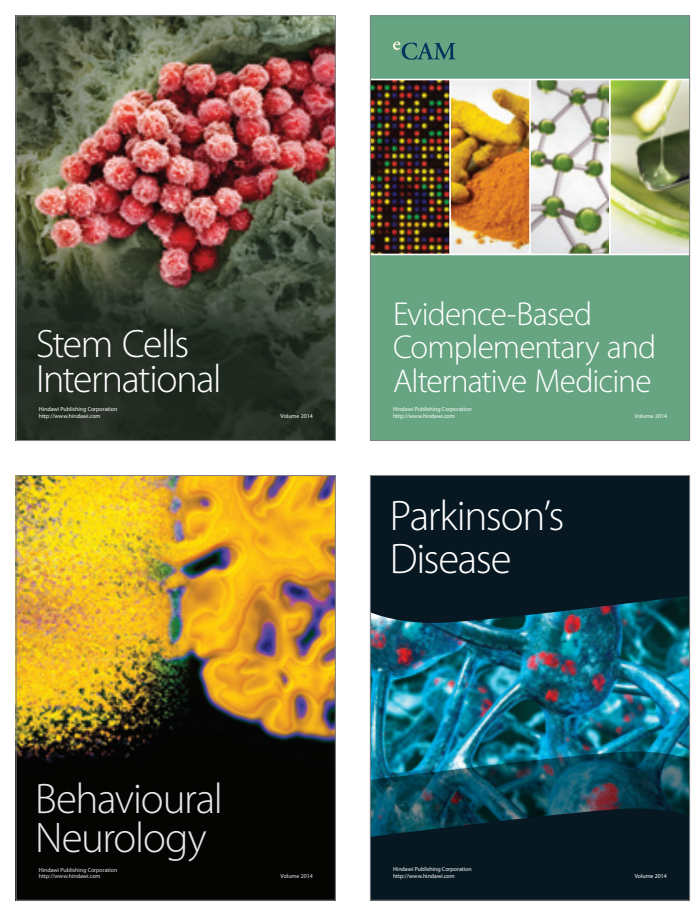

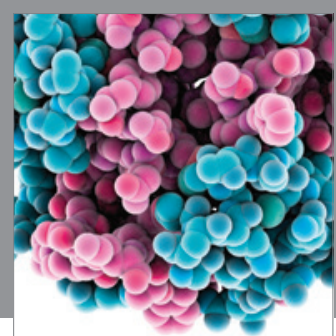

Journal of
Diabetes Research

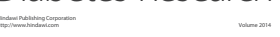

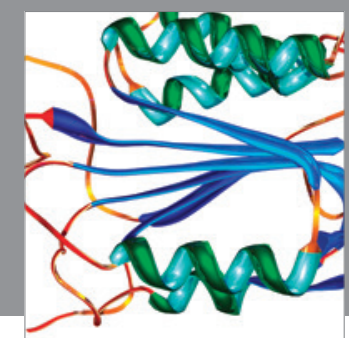

Disease Markers
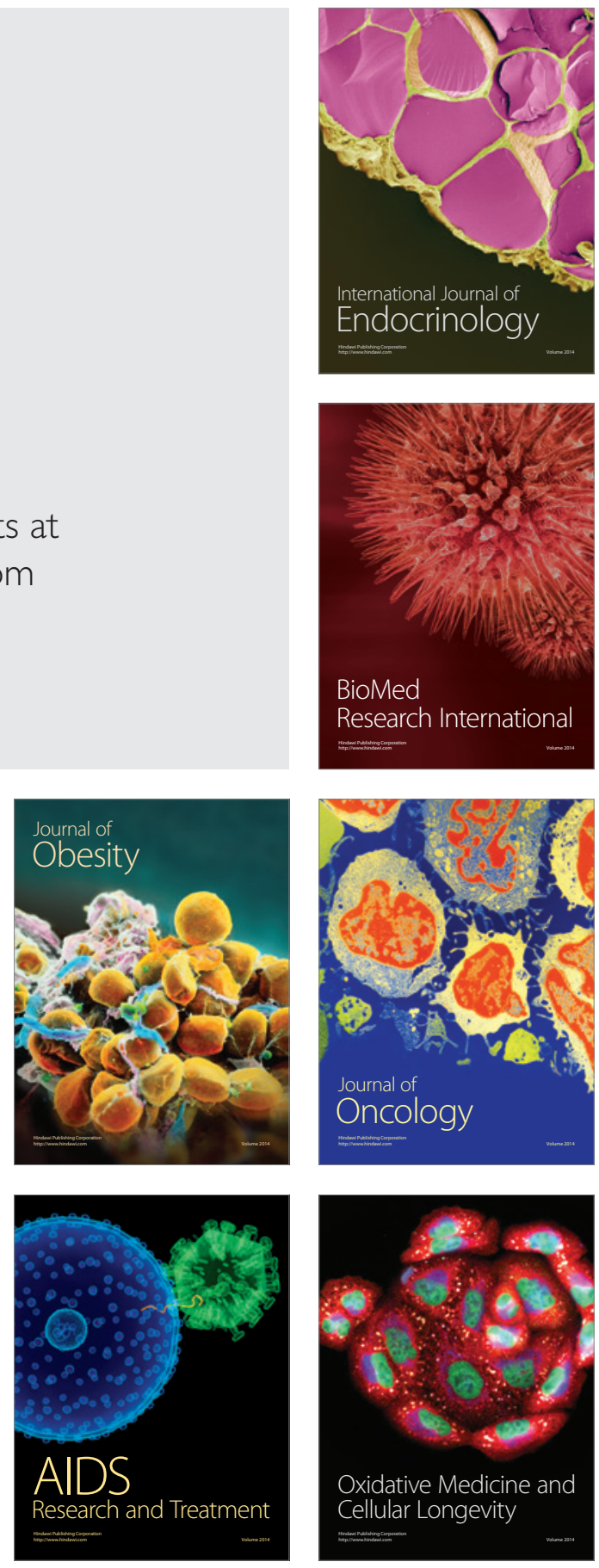